\title{
Technological Barriers and Challenges in the Use of ICT during the COVID-19 Emergency Remote Learning
}

\author{
Maila D. H. Rahiem \\ Faculty of Education, UIN Syarif Hidayatullah, 15412, Jakarta, Indonesia
}

Received August 28, 2020; Revised October 9, 2020; Accepted November 1, 2020

\section{Cite This Paper in the following Citation Styles}

(a): [1] Maila D.H. Rahiem, "Technological Barriers and Challenges in the Use of ICT during the COVID-19 Emergency Remote Learning," Universal Journal of Educational Research, Vol. 8, No. 11B, pp. 6124 - 6133, 2020. DOI: 10.13189/ujer.2020.082248.

(b): Maila D.H. Rahiem (2020). Technological Barriers and Challenges in the Use of ICT during the COVID-19 Emergency Remote Learning. Universal Journal of Educational Research, 8(11B), 6124 - 6133. DOI: 10.13189/ujer.2020.082248.

Copyright $\odot 2020$ by authors, all rights reserved. Authors agree that this article remains permanently open access under the terms of the Creative Commons Attribution License 4.0 International License

\begin{abstract}
This study aimed to examine university students' insights and observations concerning the technological barriers and difficulties they encountered in the use of Information and Communication Technology (ICT) during the COVID-19 Emergency Remote Learning (ERL). This research employed a qualitative phenomenological approach as the method of inquiry. The study included eighty university students, who studied at the Faculty of Education at a state university in Jakarta, Indonesia. Data were collected through a two-week daily journal, the students' reflective essays and an online focus group discussion. The study revealed the technology barriers and challenges in using ICT included: device issues, internet connectivity, technology costs, and lack of technology skills. Students also had problems with: incompatible devices, sharing devices with other family members, unstable internet connection, restricted or unavailable internet access, data costs, purchasing new devices, new programs or apps, inexperience with ICT, lack of ICT skills, and inadequate learning platforms. The findings of this research are useful for improving students' learning experience and access during these challenging times. COVID-19 is a recent phenomenon; it is novel to research the case, and this research offers both practical and theoretical measures to help improve ERL in the future.
\end{abstract}

Keywords Technology, ICT, Emergency Remote Learning, COVID-19, Higher Education

\section{Introduction}

COVID-19 has changed the habits and lives of people [1]-[4]. The sheer magnitude of the issue has troubled people and societies at large, and they need an urgent and long-term commitment to dealing with the situation. In the absence of vaccines, most nations responded to the COVID-19 pandemic by promptly implementing measures to contain public health, known as non-pharmaceutical interventions [5]-[7]. It is suggested that quarantine, social distancing, the isolation of infected populations, travel restrictions and school closures could all be key parameters essential to help control the current global infectious crisis [8]-[11].

Quarantine is the isolation and enforced movement restriction of people, who may have been confirmed with an infectious disease, to assess if they are unwell, thus reducing their risk of infecting others [12], [13]. Social distancing is a public health strategy intended to discourage sick people from coming into direct contact with healthy people to minimize their disease spreading potential [14][16]. As schools are supposed to be a place where people gather, and infectious diseases could easily spread, many countries are rapidly and drastically adopting the school closing strategy to restrict the transmission of COVID-19 within society.

The United Nations Educational, Scientific, and Cultural Organization [17] estimated that 195 countries had enforced national school closures in the first week of April. Such national suspensions have affected nearly 91.3 
percent of the worldwide student population or 1,598,099,000 learners. Courses have shifted from in-person learning to remote learning, primarily through the use of ICT. Remote learning due to school closures during the COVID-19 pandemic is significantly different from well-planned online learning. It is not just online learning; it is Emergency Remote Teaching (ERT) or Emergency Remote Learning (ERL) or Pandemic Pedagogy [18], [19], and these are the concepts used in this study. The shift happened all of a sudden without prior planning; it was an instant response to a crisis that occurred without warning.

Educators started using the media or methods they were used to and that were convenient to use. They were not well prepared, and many had no ideas about turning their existing learning process into learning online. This situation was certainly not ideal, but students are persistent, educators are strong-willed, and they all tried their best [20]. A mix of conventional and non-conventional methods or blended learning was utilized remotely during the COVID-19 outbreak [21]. Blended learning is the application of more than one method, strategy, technique, or media in education [22], [23]. Blended learning is a combination of conventional lectures, and web-based content [24], or traditional face-to-face learning incorporated with ICT [25].

Learning had been paradoxical during ERL; to explain how students saw learning as versatile on the one hand, but on the other, they saw it as demanding too [21]. Rahiem [21] further explained the thirteen platforms used during ERL listed by the students were: e-book/e-journals, pdf documents, YouTube videos, online meetings (Zoom, Google Meet or Microsoft Teams), WhatsApp, social media (Facebook or Instagram), Google Classroom, e-mail, Google Search Engine, Podcasts, educational websites, Audio Calls, and PowerPoint Presentations. WhatsApp was the primary tool that was used by nearly every course during the ERL period. The students commented that ERL gave them more time to be at home, take care of their well-being, spend time with relatives, and be more creative, but at the same time, they found it difficult to balance their time. They pointed out that technology, internet access and the devices used for online learning, were some of the more common problems that arose [21].

As a continuation of that research, this study investigated what kind of technology limitations and challenges in using ICT were present during ERL. This study explored this topic using the views and experiences of the students. This study is useful in highlighting the students' perspective and what they viewed as the technological problems and challenges in using ICT while studying online during ERL. This pandemic is not yet over, and many countries continue to proceed with online learning, including in Indonesia, so if the problems can be defined and analyzed, then maybe it can help to solve these issues going forward.

\section{Materials and Methods}

This research is part of a broader project on ERL in Indonesian higher education during the COVID-19 pandemic. The main research objective was to examine the application of ERL within tertiary education in Indonesia. This study focuses on a smaller part of the problem, which is about the technology barriers and ICT challenges students faced while studying at home during the COVID-19 pandemic. This study employed a qualitative phenomenological approach as the method of inquiry. Research on phenomenology examines the essence of the experience and discusses possible interpretations of a phenomenon [26], [27]. The researcher collected and analyzed insights from university students on what technology barriers they faced during emergency remote learning due to the coronavirus crisis.

The researcher employed purposive sampling methods in selecting the study participants. Eighty fourth-semester social science education students from a public university in Jakarta participated in this research. They were selected because they are articulate and willing to share their views and experiences as per the nature of a purposeful sampling method in qualitative research. They have studied in the faculty of education, and are training to become teachers themselves. They had also enrolled in some courses in pedagogy: theory of learning, the psychology of education and curriculum. The researcher assumed they would better understand the contexts and could explain the current situation better than others in a similar situation, but who studied in other faculties.

The researcher was creative in gathering data. Due to the large-scale social restrictions in place in Jakarta at the time of the research, in the absence of direct interviews, the researcher collected data from the students using written media: diaries and essays. The participants wrote their two-week daily learning experiences in a diary (May 4-18, 2020). They concluded their observations and opinions on learning during the COVID-19 outbreak in a reflective essay, compiled on May 20, 2020. Following Patton's suggestion [28] to allow data triangulation by gathering data from various data sources, the researcher also conducted two online focus group discussion sessions.

Moreover, these three kinds of data sources helped to develop a detailed understanding of the phenomenon. Discussions were held twice; each discussion lasted 120 minutes, and 40 participants attended each time (May 26 and 27, 2020). The focus group discussions were also a member check to enhance the validity and reliability of the results.

The researcher stored the data and analyzed it using the NVivo program. This software allowed the researcher to 
analyze the gathered detailed data. The researcher also created a continuous memo throughout the NVivo program, which enabled them to record ideas and evaluate the participants' thoughts, attitudes and experiences. Analytical memos provide the researcher with a way of recording their thoughts and becoming further evidence for the thesis [29].

The researcher utilized Miles, Huberman and Saldana's two-stage coding model to interpret the findings [30]. The two coding phases are not sequential events; the data had, in reality, been continuously processed. During the first cycle, every essay and diary were coded separately by the researcher. The researcher re-configured and re-analyzed the coded data in the first coding cycle during the second stage. The second-cycle coding's main objective was to describe the categorical, thematic, logical, and theoretical meaning of the first-cycle code set. The researcher revised the codes, inserted some different codes and omitted a couple of codes to imply the results of the study. The researcher made summative conclusions based on their interpretations based on the facts of the data analysis. A description of the steps in conducting this research is as follows (Figure 1. Study Procedures):

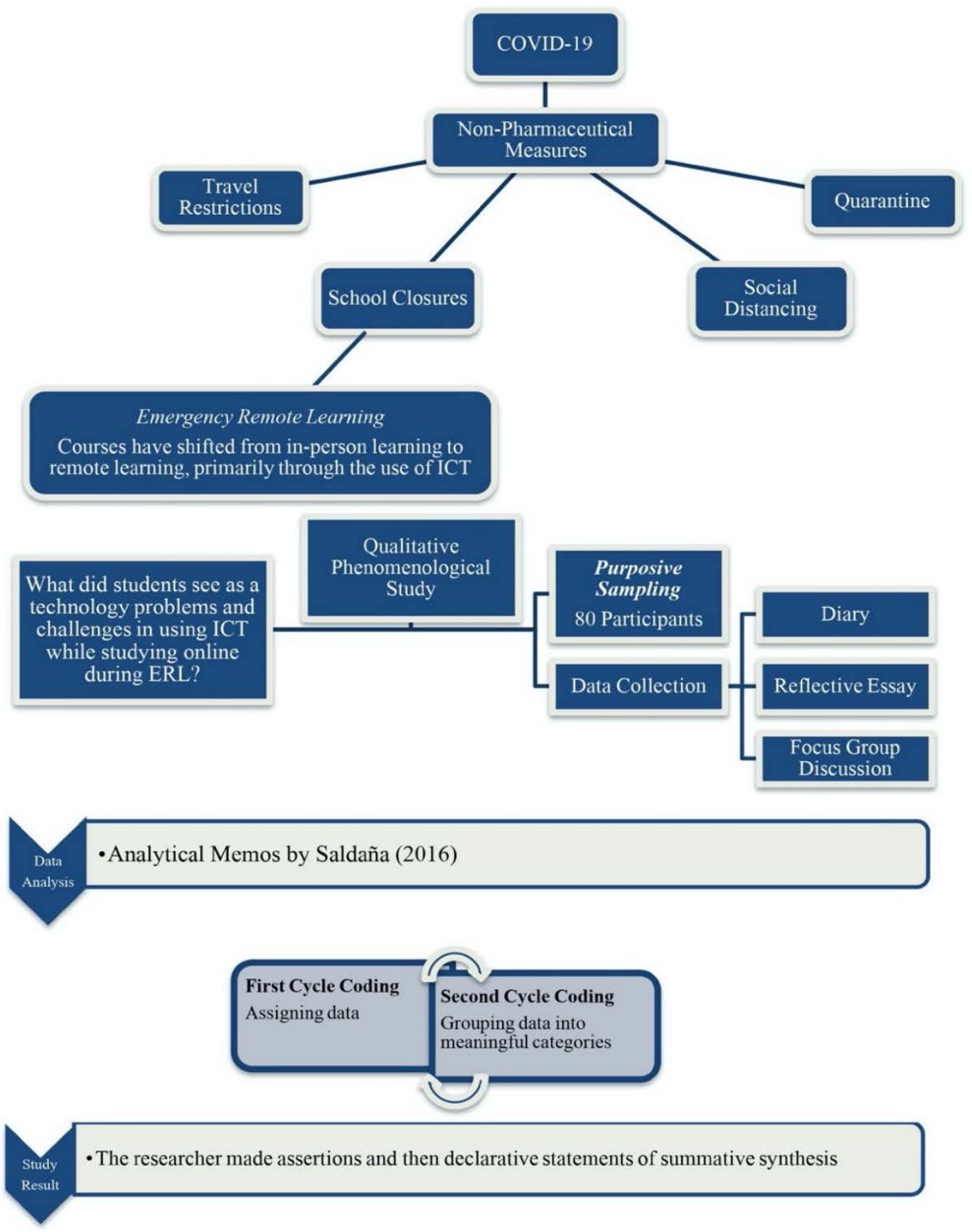

Figure 1. Study Procedures 


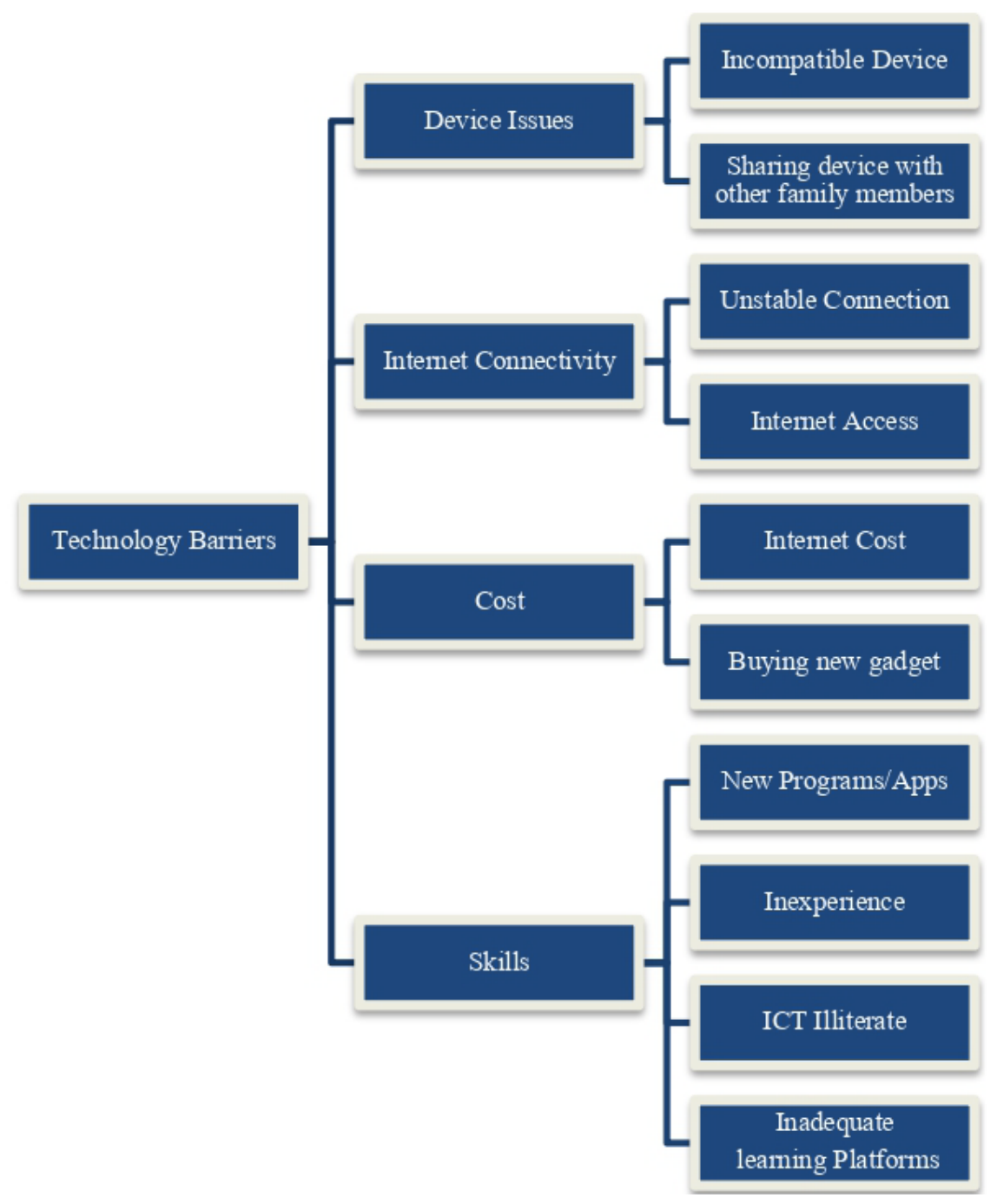

Figure 2. Research Findings

\section{Findings}

The results revealed that the technological barriers and challenges in using ICT faced by students while studying from home during the COVID-19 pandemic fell into four major themes, each with further associated sub-themes. The four themes and sub-themes described included: (a) device issues, with the sub-themes of incompatible devices, and sharing devices with other family members; (b) internet connectivity, with the sub-themes of unstable connection and limited or non-available internet access; (c) cost, with the sub-themes of internet and new gadgets; (d) skills, with the sub-themes of new programs or apps, inexperience, lack of ICT skills, and inadequate learning platforms. Above is a summary of the research findings' themes and sub-themes (Figure 2. Research Findings).

The students said they had problems with their devices not being compatible with the online learning programs, and that they often needed to share their device with other family members. This statement was said by students who have economic limitations. It did not happen to students who are well off. However, most students come from lower-middle-class backgrounds, so many of them mention this challenge.

My cellphone specs aren't that good, so it can't be used to download the application. There's not enough storage memory, so I had to remove other apps first. But even after that, I still could not open it. (4B17) It's also a little daunting because many classes in this semester need a laptop to do the assignments and projects and often online lectures require software that is just too complex for regular cell phones or laptops. (4C24)

I need to take turns using the laptop, as everything is done online. My brother and I were both studying online, and my dad also needed to use the laptop for work sometimes. My father actually has a laptop, but it's an outdated laptop, so he occasionally uses my laptop for his job. (4C20)

The students clarified that access to the Internet is one of the greatest learning challenges from home. Some students 
had poor internet connectivity, while others did not even have internet access available. As a result of the COVID-19 pandemic, schools were closed, and learning shifted to online learning, so many students returned home. The Internet network in the village is sometimes not good at all. They have to leave their house and walk to an area with good reception.

Once the campus was closed, many students returned to their hometowns. The internet network is not reliable there, and often the signal suddenly cuts off. Sometimes if we are listening to the lecturer present, it is not clear as the screen freezes or we lose sound. (4B32)

Online learning, of course, requires students to have a strong internet network, but the signal is often not smooth or just too slow. Of course, this really hinders the learning process; the material is not well transmitted, particularly during online discussions. (4C37)

I didn't get a Wi-Fi signal that was strong enough at home. So, I didn't enjoy the learning online process because I can't always understand what the lecturer said because the internet connection is unreliable. I can't get the maximum results from the online learning experience. (4B26)

They talked about the high cost of internet data plans, and some of them also needed to purchase a new computer or cellphone, so that they could join the online learning.

Not all students have enough money to buy internet data. This Internet data issue is the students' key complaint and concern regarding distance learning. (4C19)

And what I also don't like about online learning is that there are many students whose homes don't have internet subscription or Wi-Fi. They are overwhelmed by the problem. They have to spend more money to buy and provide for their own internet packages. With all due respect to the lecturers and campus leaders, they should understand that we have no money. (4B31)

I had to purchase a new smartphone because the old one was not compatible with certain apps. I had to buy a smartphone that had ample storage and decent specs. (4B22)

The students also pointed out that online learning was a new experience; there were lots of apps and programs that they had never used before. Students discussed skills and online learning platforms. They pointed out that some lecturers were inexperienced in using ICT themselves, which also delayed or slowed down the learning process. Several students also lacked the ICT skills required and found operating the required programs difficult.

Zoom, Google Classroom, Doc Google, Meet Google are all new. Some lecturers have previously used Google Classroom but not many, and if they did it was only occasionally. We got to know a lot, about new technology (4B28).

Certain lecturers do not understand any technology or ICT, so there is a definite cultural shock. Lecturers have to be able to master the program or applications used in this distance learning. (4B3).

I am not used to continuously studying at the computer. Typically, I just use it to write papers using MSWord or make presentations in PowerPoint. I was frustrated when I had to present my project using zoom, I didn't know which button to press, let alone all the commands in the program, which are in English (4C23).

Because the lecturer is using zoom, my data plan is not sufficient and runs out very fast, so I have to buy more. (C22)

\section{Discussion}

The Covid-19 pandemic has raised tremendous obstacles for the world's higher education sector. A major concern has been the urgent and unexpected need to offer online courses for previously face-to-face learning courses. This has encouraged educators to enhance learning opportunities and build distinctive learning environments through technological advancements [31]. It has intensified the need for new ways to improve educational efforts. Many educational programs have tried using new technology in an attempt to adapt [32]. The COVID-19 pandemic has caused huge, immediate, and unforeseen changes in population usage of emerging technology and media [33].

Digital inequality has risen with the COVID-19 pandemic [34]. Those with secure internet access and a high-quality technology will excel in learning while those who do not face learning difficulties. Students in this research said that they had issues with their computers that were not compatible with the programs used for the class and also needed to share their computers with other family members. Beunoyer et al. [34] identified digital inequality during COVID-19 in four ways: technological means, the autonomy of use, social support networks and experience. Their study results did not differ from this study's findings.

Students found it a challenge to study online from home. Only a few had devices that give them full access to learning. Students said they had difficulty accessing some of the programs or software (used by the lecturers) during their study, such as Zoom. Some students were expected to share a desktop or laptop with other family members. Students and their siblings have all been studying at home and parents working at home, while there is only one computer. They, therefore, needed to take turns to use it. They used to use the computers in the campus library in the pre-COVID days or share with friends, which because 
of the lock-down was impossible.

Low-income families are probably less well prepared in terms of the amount and functionality of technical equipment and also suffer more deeply from both the immediate and long-term economic effects of the COVID-19 crisis [35]-[39]. It could also be seen from the student's explanation that students who come from low-income families suffer because they cannot study well, since they do not have access to the technology required, which often hinders them.

Whereas schooling for children from higher-income households may proceed unimpeded, children from lower-income households are likely to fail to complete homework and online courses because of their precarious housing circumstances. Nevertheless, in addition to the educational difficulties, low-income families face an unexpected threat: the current pandemic is likely to result in a significant economic recession. Many of the students' parents suffered a decline in income or even lost their jobs. Under these circumstances, the upgrading or purchase of technical equipment is unlikely to rank high in the priority of those families' budgets.

Students do not have any other alternative but to study with outdated devices. These devices often cause longer delays in accessing online resources, which can produce a less enjoyable experience, resulting in a reduced opportunity to use the internet and, therefore, fewer opportunities to improve their digital literacy skills and finish assignments. In comparison, households that are more economically favored would have a strong motivation to upgrade their equipment for work, schooling or entertainment. This would lead to a worsening of digital disparities dependent on pre-existing equipment. The disparity seems unjust, and the complexity of the technical systems affects student achievement further [40].

Many students returned to their hometowns when the campus closed, and learning was conducted online at home. Those in rural or remote areas had limited Internet connection capability, and several did not even have internet access. It is these technical difficulties for students that were the second barrier to using ICT during ERT. The location of learning during the ERT time was one of the factors determining learning success, which was very advantageous if they were in a location that had a strong and consistent internet network as they could study better. This location and internet connectivity issue has proved to be a learning barrier in an archipelagic country like Indonesia.

The digital divide is the consequence of the divide of ICT infrastructure, population ICT skills, and ICT usage [41]; telecommunications network distribution [42], [43]; and regional barriers and spatial disparities [40] In Indonesia, some residents on remote islands still do not have basic telecommunications services. Unreasonable access to telecommunications networks and facilities is among the difficulties of bridging the digital divide, and remedying it should be a goal of all developing countries [40].

Spatial inequality is an incredibly common phenomenon in developing countries [40], including Indonesia. Purbo [44] reported that most internet users in Indonesia reside in the country's western region, especially Java, where internet connectivity has reached 36.9 percent. Around 83 percent of users live in urban areas, but in Indonesia's largest cities, there is a digital gap among those who have daily internet access (less than 20 percent of urban residents) from those who do not (more than 80 percent). Indonesia is a 'mobile-first' country, with approximately 85 percent of existing internet users using a mobile computer. There are significant differences in the digital use of the internet in urban and rural areas [45]. The best cellular service is in the cities and the worst in rural areas and villages; it is difficult to have wireless mobile phone coverage in remote regions because of the need to build networks that can resolve physical obstacles like mountainous areas.

Wilantika et al. [46] used the Digital Divide Index (DIDIX) developed by Hüsing and Selhofer to calculate and quantify the digital divide that occurred in 34 Indonesian provinces. The results suggested that there was one province with low digital divide rates (Jakarta, the nation's capital city), 19 provinces with medium digital divide rates, and 14 provinces with high digital divide rates. Provinces with a high digital divide are not clustered in one island. However, it does typically occur in eastern Indonesia's outermost provinces and districts. Of the 14 high digital dividing provinces, five are located on Sumatera Island, namely Aceh, North Sumatera, Jambi, Bengkulu, and Riau Islands, two are located on Java Islands, in neighboring Yogyakarta, Banten, and Bali. In contrast, the other six are located on Sulawesi, Maluku, and Papua Islands.

Students in this research are studying at a Jakarta-based university. Most returned home because the campus was closed. Nevertheless, their homes are mainly located in Jakarta and the surrounding area. The remaining small minority reside in other places on the island of Java or Sumatra primarily. Despite most students staying in Jakarta, there was still a large proportion that complained about unreliable Internet access. While Jakarta's digital divide is the lowest in Indonesia, it does not mean that access to ICT for its population is now without its problems. From data from SUSENAS 2016, it is understood that 30.72 percent of Jakarta's population lacks a cell phone. It was also found that the percentage of Jakarta's population that has used the internet is 45.84 percent. This means that over half of Jakarta's population has never used the internet [46].

Digital disparities also have implications for individuals' daily lives [47]-[49]. The absence of a good network has implications [50]for the performance of 
students. Especially when there are lecturers who offer short-term quizzes, and students are expected to submit answers before the time is up. It is indeed a frustration, and this challenge could impact the students' grades and learning progress.

The students conveyed their difficulties in purchasing data plans. They talked about the high cost of spending money on an internet data plan, and several of them also needed to buy new computers so that they could undertake online learning. They explained that they did not get pocket money from their parents or extra earnings from working part-time as they had previously.

Connectivity and usage of the Internet in Pre-COVID-19 was typically not a prerequisite - albeit a possibility - for all because some people would normally work without it in most areas of social life, either because of help from others or simply because their social context did not need it [34]. Nevertheless, during this global shutdown that breaks down interpersonal relationships, it is vital to maintain our fundamental social structures, the position of virtual digital spaces has shifted from an amenity to an imperative [51].

Expenditure on internet connectivity has risen several times more than average, with many worrying about how they will find the additional money needed to cover this extra cost. With increasing unemployment, this was a major concern for many. Unfortunately, Internet data is a basic requirement for gaining good grades and seeing a progression in learning. No matter how hard the student study, they will not get perfect scores if they do not have access to the internet. Their learning success is linked to whether there is money to buy a data plan. Compared to the lowest, highest-income individuals have almost a five-time higher chance of accessing the internet [18]. Digital inequality does make learning outcomes unfair.

The students also pointed out that studying online was a new concept; there were many applications and programs that they had never used before. They also pointed out that some lecturers themselves were inexperienced in using ICT and that the learning was delayed or slower than previously with face-to-face learning. Several students lacked the skills required to use ICT effectively and found it difficult to run the programs needed to conduct their studies.

Teachers of all backgrounds and ages have had to plan and deliver their classes from home, with all the logistical and technological difficulties that this entails, and sometimes without sufficient professional assistance [52]. The students explained how teachers and students learned new skills and adjusted to new forms of learning and teaching together during the first month of school closures. In this time of crisis, learning was packed with extensive tests of trial and error. The students agreed that they found the first month of ERT very stressful. Educational institutions should carefully consider their online learning options and technology in education [52]; so, that the learning can be more easily accessible for both students and lecturers, regardless of their technological capability.

Presently (July, 2020), most universities are in the middle of a semester break. This is a crucial moment for these educational institutions to reflect upon the effect of Covid-19 on education, and how online learning could affect the students: will they perpetuate the neoliberal instrumental view of education or encourage holistic human growth? [18]. Many online emergency learning methods are criticized for lacking sound pedagogical standards, best practices, and earlier work [53], [54]. The health emergency requires educators to race to select which media and strategies should be implemented, and it will often be introduced before it has been tested comprehensively. The technology's introduction without considering its implications [55]-[58] is an area that requires further investigation. The widespread use of digital networks and streaming media has raised concerns about privacy and surveillance, and the effect on students' lives and integrity [59].

Another issue of concern is how learning is prioritized based on the technologies employed, not the content of learning. Cortois and Verdegem [60], differentiate between medium-based competencies and competencies related to content. The former includes organizational skills, i.e., the fundamental skills in managing Internet technology, and structured skills, i.e., skills related to manipulating the internet's hyper-structure. The latter set of skills includes information skills, i.e., the literacy skills needed to search for information, and analytical skills that may be called meta-skills as they conceive goal-driven approaches to achievement to the degree to which they are as efficient and successful as possible. In reality, both are required in the teaching. Teachers must incorporate learning media and content to produce meaningful and practical learning that is presented attractively, making it easier for students to study independently.

What is an ideal teaching method during ERL? Sunasee [60] argues that a mixture of asynchronous and synchronous teaching methods has been found to be successful in delivering information, active learning, and student involvement. Synchronous attendance in class was tracked and contrasted with the usual face-to-face attendance in class. Synchronous problem-solving activities affected the success rate and performance of the students. An exit survey showed that about 64 percent of students favored face-to-face teaching online [60]. To replicate the face-to-face learning experiences, Zoom's use as a medium for online content distribution and real-time teaching has been strongly encouraged. Originally, using the Zoom framework for synchronous instruction was a technical obstacle for both teachers and students to adjust rapidly to the modern learning environment in Zoom [31].

In addition to understanding the content being taught and how to teach it, educators need to understand the technical and logistical aspects of online education, such 
as using platforms and resources and managing workflows. More specifically, it provides the pedagogical foundations and awareness of the concepts required to create effective online learning environments and promote them [61]. ICT helps to solve learning barriers [62]; If it is used correctly and appropriately.

Now, six months after studying from home first began, educators and learners are tending to make changes and improvements. Barriers to technology and the obstacles students face when using ICT should be the concern of all parties. We are not sure when students will be allowed to return to the campus to study. All these new virtual initiatives are expected, but technological challenges can be handled as users become more familiar with the system and local knowledge emerges. That said, this innovative platform's primary challenge lies in the faculty's willingness to accept the technology [63]. Zoom is a good example of this, as both students and lecturers have adapted to use it more effectively; the use of breakout rooms, which is a benefit for teachers aiming to replicate the classroom environment, indicates this progression.

\section{Conclusions}

COVID-19 is not the first virus that has affected humankind, nor will it be the last [63]. We need to use innovative approaches to improve institutional skills and readiness, education leaders and management, educators and students to address the challenges underway. The rapid transformation has exposed inconsistencies and weaknesses in how online learning has been or has not been implemented in educational institutions. The implications of digital inequality should be key in policy responses to COVID-19 vulnerability. Is technology going to fix the problem? Are there any less technical models in use that are more suited to regions lacking a reliable internet connection? Such situations and circumstances often point to how unprepared our educational institutions are to cope with an emergency. Barriers to technology and the challenges students and educators encounter by using ICT. It is a warning and reflection; we need to plan better for the unparalleled potential threat to education, specifically and human life in general. The curriculum should be able to be quickly turned into online learning, equip students and educators with ICT knowledge and skills, and the networking network should provide broader exposure for all people to eliminate any gaps in internet accessibility and ICT services.

\section{Acknowledgements}

The researcher honors the students involved in this study for their excellent contributions, making notes on day-to-day learning activities, writing reflective essays and attending online focus group discussions. They have chosen to remain anonymous. The researcher also wishes to express deep thanks to Adam Batten for his review and constructive feedback during the production of this writing.

\section{REFERENCES}

[1] Y. Zhang and Z. F. Ma, "Impact of the COVID-19 Pandemic on Mental Health and Quality of Life among Local Residents in Liaoning Province, China: A Cross-Sectional Study," International Journal of Environmental Research and Public Health, vol. 17, no. 7, p. 2381, Mar. 2020, doi: 10.3390/ijerph17072381.

[2] A. Madani, S. E. Boutebal, and C. R. Bryant, "The Psychological Impact of Confinement Linked to the Coronavirus Epidemic COVID-19 in Algeria,” International Journal of Environmental Research and Public Health, vol. 17, no. 10, p. 3604, May 2020, doi: 10.3390/ijerph17103604.

[3] L. di Renzo et al., "Psychological Aspects and Eating Habits during COVID-19 Home Confinement: Results of EHLC-COVID-19 Italian Online Survey,” Nutrients, vol. 12, no. 7, p. 2152, Jul. 2020, doi: 10.3390/nu12072152.

[4] F. P. Ibarra et al., "Impact of the COVID-19 pandemic on the sexual behavior of the population. The vision of the east and the west," International braz j urol, vol. 46, no. suppl 1, pp. 104-112, Jul. 2020, doi: 10.1590/s1677-5538.ibju.2020.s11 6.

[5] R. Djidjou-Demasse, Y. Michalakis, M. Choisy, M. T. Sofonea, and S. Alizon, "Optimal COVID-19 epidemic control until vaccine deployment,” 2020. doi: 10.1101/2020.04.02.20049189.

[6] S. Flaxman et al., "Estimating the effects of non-pharmaceutical interventions on COVID-19 in Europe," Nature, vol. 584, no. 7820, pp. 257-261, Aug. 2020, doi: 10.1038/s41586-020-2405-7.

[7] B. J. Cowling et al., "Impact assessment of non-pharmaceutical interventions against coronavirus disease 2019 and influenza in Hong Kong: an observational study," The Lancet Public Health, vol. 5, no. 5, pp. e279e288, May 2020, doi: 10.1016/S2468-2667(20)30090-6.

[8] R. M. Anderson, H. Heesterbeek, D. Klinkenberg, and T. D. Hollingsworth, "How will country-based mitigation measures influence the course of the COVID-19 epidemic?," The Lancet, vol. 395, no. 10228, pp. 931-934, Mar. 2020, doi: 10.1016/S0140-6736(20)30567-5.

[9] S. Cauchemez et al., "Closure of schools during an influenza pandemic,” The Lancet Infectious Diseases, vol. 9, no. 8, pp. 473-481, Aug. 2009, doi: 10.1016/S1473-3099(09)70176-8.

[10] S. Cauchemez, A.-J. Valleron, P.-Y. Boëlle, A. Flahault, and N. M. Ferguson, "Estimating the impact of school closure on influenza transmission from Sentinel data," Nature, vol. 452, no. 7188, pp. 750-754, Apr. 2008, doi: 10.1038/nature06732.

[11] M. Chinazzi et al., "The effect of travel restrictions on the 
spread of the 2019 novel coronavirus (COVID-19) outbreak,” Science, p. eaba9757, Mar. 2020, doi: 10.1126/science.aba9 757.

[12] S. K. Brooks et al., "The psychological impact of quarantine and how to reduce it: rapid review of the evidence," The Lancet, vol. 395, no. 10227, pp. 912-920, Mar. 2020, doi: 10.1016/S0140-6736(20)30460-8.

[13] CDC, “Quarantine and Isolation | Quarantine | CDC,” Cdc. 2017.

[14] M. Greenstone and V. Nigam, "Does Social Distancing Matter?,” SSRN Electronic Journal, 2020, doi: 10.2139/ssrn.3561244.

[15] K. Pearce, "WHAT IS SOCIAL DISTANCING AND HOW CAN IT SLOW THE SPREAD OF COVID-19?,” John Hopkins University, 2020.https://hub.jhu.edu/2020/03/13/w hat-is-social-distancing/.

[16] M. W. Fong et al., "Nonpharmaceutical Measures for Pandemic Influenza in Nonhealthcare Settings-Social Distancing Measures,” Emerging Infectious Diseases, vol. 26, no. 5, pp. 976-984, May 2020, doi: 10.3201/eid2605.190995.

[17] UNESCO, “COVID-19 Impact on Education,” 2020. https://en.unesco.org/covid19 (accessed Jun. 12, 2020).

[18] C. Hodges, S. Moore, B. Lockee, T. Trust, and A. Bond, "The Difference Between Emergency Remote Teaching and Online Learning,” Educause Review, 2020.

[19] N. B. Milman, "Pandemic pedagogy,” Phi Delta Kappan, 2020.

[20] A. J. Juliani, “THIS IS NOT ONLINE OR DISTANCE LEARNING,” A.J. Juliani, 2020.

[21] M. D. H. Rahiem, "The Emergency Remote Learning Experience of University Students in Indonesia amidst the COVID-19 Crisis," International Journal of Learning, Teaching and Educational Research, vol. 19, no. 6, pp. 1-26, Jun. 2020, doi: 10.26803/ijlter.19.6.1.

[22] R. Sadeghi, M. M. Sadaghat, and F. S. Ahmadi, "Comparison of the Effect of Lecture and Blended Teaching Methods on Students' Learning and Satisfaction,” J. Adv Med Ed Prof, vol. 2, no. 4, pp. 146-150, 2014.

[23] J. E. Thiele, “Learning Patterns of Online Students,” Journal of Nursing Education, vol. 42, no. 8, pp. 364-6, 2003.

[24] F. Concannon, A. Flynn, and M. Campbell, "What campus-based students think about the quality and benefits of e-learning,” British Journal of Educational Technology, vol. 36, no. 3, pp. 501-512, May 2005, doi: 10.1111/j.1467-8535.2005.00482.x.

[25] M. Farrel, "Learning differently: e-learning in nurse education,” Nursing Management, vol. 13, no. 6, pp. 14-17, Oct. 2006, doi: 10.7748/nm.13.6.14.s12.

[26] F. L. Casmir, "Phenomenology and hermeneutics: Evolving approaches to the study of intercultural and international communication," International Journal of Intercultural Relations, vol. 7, no. 3, pp. 309-324, 1983, doi: 10.1016/0147-1767(83)90035-4.

[27] A. F. N. MacDermott, "Living with angina pectoris - A phenomenological study,” European Journal of
Cardiovascular Nursing, 2002, doi: 10.1016/S1474-5151(0 2)00047-6.

[28] M. Q. Patton, "Enhancing the quality and credibility of qualitative analysis.," Health services research, 1999.

[29] J. Saldaña, “The Coding Manual for Qualitative Researchers (No. 14),” Sage, 2016.

[30] M. B. Miles, M. a Huberman, and J. Saldana, "Drawing and Verying Conclusions,” Qualitative Data Analysis: A Methods Sourcebook, 2014, doi: January 11, 2016.

[31] C. Rapanta, L. Botturi, P. Goodyear, L. Guàrdia, and M. Koole, "Online University Teaching During and After the Covid-19 Crisis: Refocusing Teacher Presence and Learning Activity,” Postdigital Science and Education, Jul. 2020, doi: 10.1007/s42438-020-00155-y.

[32] Z. I. Almarzooq, M. Lopes, and A. Kochar, "Virtual Learning During the COVID-19 Pandemic," Journal of the American College of Cardiology, vol. 75, no. 20, pp. 2635 2638, May 2020, doi: 10.1016/j.jacc.2020.04.015.

[33] M. J. Guitton, "Swimming with mermaids: Communication and social density in the Second Life merfolk community," Computers in Human Behavior, vol. 48, pp. 226-235, Jul. 2015, doi: 10.1016/j.chb.2015.02.004.

[34] E. Beaunoyer, S. Dupéré, and M. J. Guitton, “COVID-19 and digital inequalities: Reciprocal impacts and mitigation strategies,” Computers in Human Behavior, vol. 111, p. 106424, Oct. 2020, doi: 10.1016/j.chb.2020.106424.

[35] W. van Lancker and Z. Parolin, "COVID-19, school closures, and child poverty: a social crisis in the making," The Lancet Public Health, vol. 5, no. 5, pp. e243-e244, May 2020, doi: 10.1016/S2468-2667(20)30084-0.

[36] J. Mikolai, K. Keenan, and H. Kulu, "Intersecting household level health and socio-economic vulnerabilities and the COVID-19 crisis: An analysis from the UK," SSM Population Health, p. 100628, Jul. 2020, doi: 10.1016/j.ssmph.2020.100628.

[37] R. Blundell, M. Costa Dias, R. Joyce, and X. Xu, "COVID 19 and Inequalities*,” Fiscal Studies, vol. 41, no. 2, pp. 291319, Jun. 2020, doi: 10.1111/1475-5890.12232.

[38] M. Nicola et al., "The socio-economic implications of the coronavirus pandemic (COVID-19): A review," International Journal of Surgery, vol. 78, pp. 185-193, Jun. 2020, doi: 10.1016/j.ijsu.2020.04.018.

[39] C. Arndt et al., "Covid-19 lockdowns, income distribution, and food security: An analysis for South Africa," Global Food Security, vol. 26, p. 100410, Sep. 2020, doi: 10.1016/j.gfs.2020.100410.

[40] S. Sujarwoto and G. Tampubolon, "Spatial inequality and the Internet divide in Indonesia 2010-2012," Telecommunications Policy, vol. 40, no. 7, pp. 602-616, Jul. 2016, doi: 10.1016/j.telpol.2015.08.008.

[41] R. Handayani and G. Afrizal, "Thin Clients as Memoryless Computer for Reducing Digital Divide in East Indonesia,” in 2018 12th International Conference on Telecommunication Systems, Services, and Applications (TSSA), Oct. 2018, pp. 1-5, doi: 10.1109/TSSA.2018.8708828.

[42] J. Mariscal, "Digital divide in a developing country," 
Telecommunications Policy, 2005, doi: 10.1016/j.telpol.200 5.03.004.

[43] S. S. Rao, “Bridging digital divide: Efforts in India,” 2005, doi: 10.1016/j.tele.2005.01.007.

[44] O. W. Purbo, "Digital Indonesia: Connectivity and Divergence," in Narrowing the digital divide, E. Jurriens and R. Tapsell, Eds. Singapore: ISEAS-Yusof Ishak Institute, 2017, pp. 75-92.

[45] K. Onitsuka, A. R. T. Hidayat, and W. Huang, "Challenges for the next level of digital divide in rural Indonesian communities," The Electronic Journal of Information Systems in Developing Countries, vol. 84, no. 2, p. e12021, Mar. 2018, doi: 10.1002/isd2.12021.

[46] N. Wilantika, D. I. Sensuse, S. B. Wibisono, P. L. Putro, and A. Damanik, "Grouping of Provinces in Indonesia According to Digital Divide Index,” in 2018 6th International Conference on Information and Communication Technology (ICoICT), May 2018, pp. 380 388, doi: 10.1109/ICoICT.2018.8528753.

[47] M. Büchi, N. Just, and M. Latzer, "Modeling the second-level digital divide: A five-country study of social differences in Internet use," New Media \& Society, vol. 18, no. 11, pp. 2703-2722, Dec. 2016, doi: $10.1177 / 1461444815604154$.

[48] M. Gilbert, “THEORIZING DIGITAL AND URBAN INEQUALITIES,” Information, Communication \& Society, vol. 13, no. 7, pp. 1000-1018, Oct. 2010, doi: 10.1080/1369118X.2010.499954.

[49] N. Zillien and E. Hargittai, "Digital Distinction: Status-Specific Types of Internet Usage," Social Science Quarterly, vol. 90, no. 2, pp. 274-291, Jun. 2009, doi: 10.1111/j.1540-6237.2009.00617.x.

[50] P. Lupač, Beyond the digital divide: Contectualizing the information society. Bingley: Emerald Publishing, 2018.

[51] M. Haight, A. Quan-Haase, and B. A. Corbett, "Revisiting the digital divide in Canada: the impact of demographic factors on access to the internet, level of online activity, and social networking site usage," Information, Communication \& Society, vol. 17, no. 4, pp. 503-519, Apr. 2014, doi: 10.1080/1369118X.2014.891633.

[52] M. Teräs, J. Suoranta, H. Teräs, and M. Curcher, "Post-Covid-19 Education and Education Technology 'Solutionism': A Seller's Market,” Postdigital Science and Education, Jul. 2020, doi: 10.1007/s42438-020-00164-x.

[53] M. st. Amor, "Privacy and the Online Pivot,"
Insighthighered, 2020. https://www.insidehighered.com/ne ws/2020/03/25/pivot-online-raises-concerns-ferpa-surveilla nce.

[54] N. Selwyn, "After COVID-19: The Longer-Term Impacts of the Coronavirus Crisis on Education,” Education Futures, Monash University, 2020. https://educationfutures.monash. edu/all---present/after-covid-19.

[55] P. C. Kumar, M. Chetty, T. L. Clegg, and J. Vitak, "Privacy and Security Considerations for Digital Technology Use in Elementary Schools," in Proceedings of the 2019 CHI Conference on Human Factors in Computing Systems CHI '19, 2019, pp. 1-13, doi: 10.1145/3290605.3300537.

[56] S. Athey, C. Catalini, and C. Tucker, "The Digital Privacy Paradox: Small Money, Small Costs, Small Talk," Cambridge, MA, Jun. 2017. doi: 10.3386/w23488.

[57] M. Sideri, A. Kitsiou, E. Tzortzaki, C. Kalloniatis, and S. Gritzalis, "Enhancing university students' privacy literacy through an educational intervention: a Greek case-study," International Journal of Electronic Governance, vol. 11, no. 3/4, p. 333, 2019, doi: 10.1504/IJEG.2019.103719.

[58] H. Leatham and L. Robertson, "Student Digital Privacy in Classrooms: Teachers in the Cross-currents of Technology Imperatives,” International Journal for Digital Society, vol. 8, no. 1, pp. 1260-1267, Mar. 2017, doi: 10.20533/ijds.2040.2570.2017.0155.

[59] C. Courtois and P. Verdegem, "With a little help from my friends: An analysis of the role of social support in digital inequalities," New Media \& Society, vol. 18, no. 8, pp. 15081527, Sep. 2016, doi: 10.1177/1461444814562162.

[60] R. Sunasee, "Challenges of Teaching Organic Chemistry during COVID-19 Pandemic at a Primarily Undergraduate Institution," Journal of Chemical Education, p. acs.jchemed.0c00542, Jul. 2020, doi: 10.1021/acs.jchemed. 0c00542.

[61] D. O’Doherty, M. Dromey, J. Lougheed, A. Hannigan, J. Last, and D. McGrath, "Barriers and solutions to online learning in medical education - An integrative review," BMC Medical Education. 2018, doi: 10.1186/s12909-018-1240-0.

[62] T. Mølster and K. Nes, “To What Extent Does Information and Communication Technology Support Inclusion in Education of Students with Learning Difficulties?," Universal Journal of Educational Research, vol. 6, no. 4, pp. 598-612, Apr. 2018, doi: 10.13189/ujer.2018.060403.

[63] L. Cluver et al., "Parenting in a time of COVID-19," The Lancet, vol. 395, no. 10231, p. e64, Apr. 2020, doi: 10.1016/S0140-6736(20)30736-4. 